\title{
Hydrogeo-Electric Characteristics of Upper River Shemankar Basin, Jos Plateau: A Case Study of Jibam and Environs.
}

\author{
* Longpia, C.B, ** Dakwo, P.D \& *** Lar, U. A \\ * Dept. of Mineral Resources Engineering, Plateau State Polytechnic Barkin Ladi. \\ ** Lonpigrand Geotechnics Nig. Ltd. Jos. \\ *** Dept. of Geology \& Mining, University of Jos, Jos.
}

\begin{abstract}
A detailed hydrogeo-electric investigation of Jibam Village and environs was carried out to determine the peculiar difficult hydrogeological disposition of the area which result in well and borehole failures. The area is underlain by Basement Complex rocks (migmatites, granite gneiss and pegmatites) and Newer basalts. A total of 70 vertical electrical sounding (VES) were carried out within the study area. The field data were interpreted using computer aided programe (Win Resists) and from the geo-electric parameters, 4-5 geoelectirc layers were identified which include-Topsoil from 0-3.8m, Weathered basement/basalt from 0.1$21 \mathrm{~m}$, Basalt/fractured basalt from 0.1-20m, Sub-basalt alluvium from 20-30m and Fresh basement from 10.1$\infty \mathrm{m}$, and characterized by variable resistivity value range from $93-634 \mathrm{ohm} / \mathrm{m}, 23-152 \mathrm{ohm} / \mathrm{m}, 178-693 \mathrm{ohm} / \mathrm{m}$, $28-70 \mathrm{ohm} / \mathrm{m}$ and 100-1296 ohm/m respectively. The interpreted geoelectric parameters from the VES model curves were used to produce geo-electric sections, isopach maps, bedrock relief/structural maps which aided in the development of the overall groundwater potential map of the area. This study revealed that basement depressions with moderate overburden and areas underlain by sub-basalt alluvium and/or fractured basalts are areas with low and medium-high groundwater potential respectively.
\end{abstract}

Keywords: Hydrogeo-electric investigation, Basement Complex rocks, Basalts, VES model curves, River Shemankar and Jos Plateau.

\section{Introduction}

Jibam and environs, lies within the upper ridges of the River Shemankar (Fig. 1a) between latitudes 9.1389 $\mathrm{N}$ and $9.1979 \mathrm{~N}$ and longitudes $9.3211 \mathrm{E}$ and $9.3361 \mathrm{E}$ (Fig. 1b). The adjoining communities include Zong, Mhies, Kapil and Jing and it covers a total land area of about $21 \mathrm{~km}^{2}$.

The study area lies within the Gu volcanic provinces. This volcanic province consists of a series of six volcanic vents aligned in NE-SW direction along a hypothetical fissure through the earthcrust. It is part of the product of the uplift of the Jos Plateau that occurred shortly before the end of the Tertiary and was occupied by volcanism and denudation (Ajaegbu et'al, 1992). The study area sits within a valley filled with basalts flows and is characterized by undulating terrain with ridging; and is dissected by rivers/valleys to the northern extreme of the basin. The river and/ or valleys, have been filled by basalt flows and apparently modifying the pre-volcanic drainage network.

Jibam and environs have a peculiar problem of high borehole and/ well failures as a result of shallow weathered basement overburden and where fractures are encountered, they are generally dry. Inhabitants of these c0mmunities source their water for domestic use mainly from the gorge river with its quality highly questionably, as a result of prevalence of water related diseases. It is this high failure rate that has prompted the need to determine the detailed hydrogeophysical characteristics/deposition of the area in order to capture the cause of the failures/and increase the boreholes drilling success within the environs. 


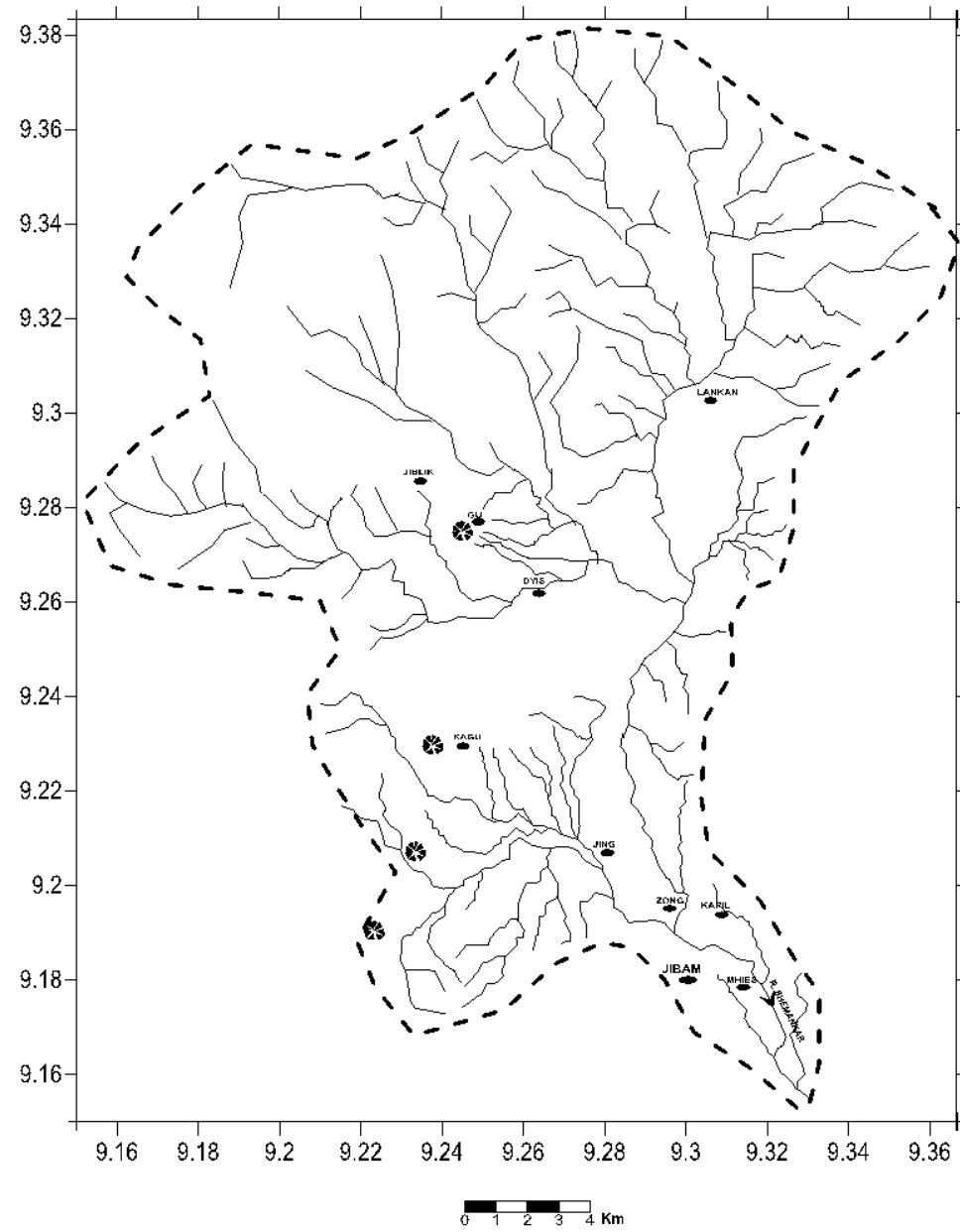

$\tilde{\Lambda}$

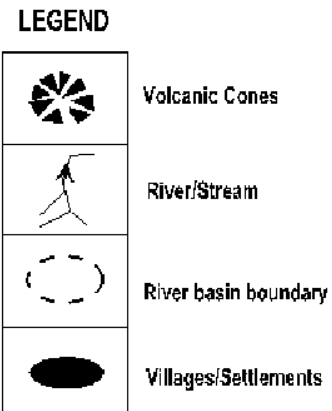

Fig. 1a: Map of Upper River Shemankar Basin.

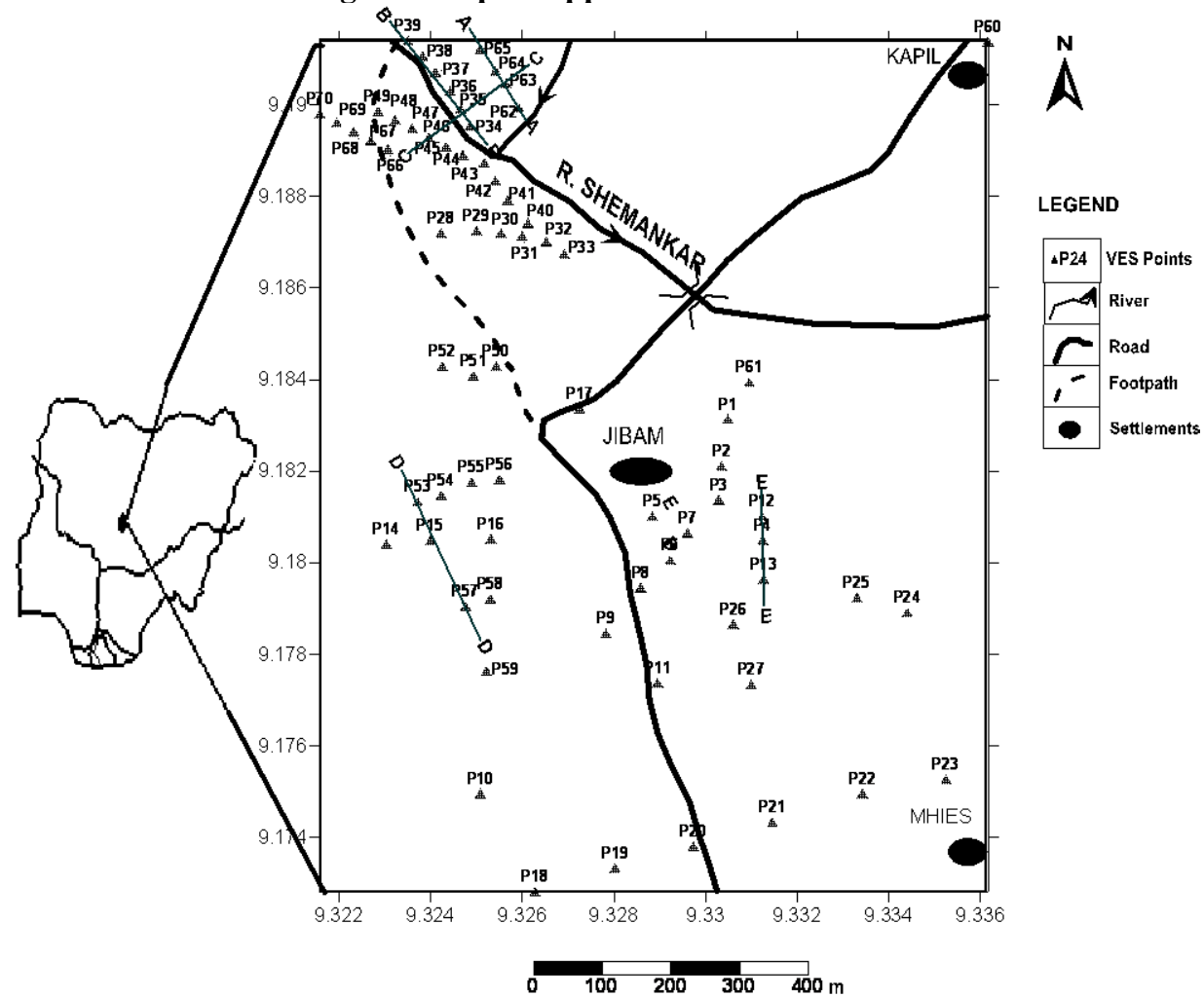

Fig. 1b: Location Map of the Study area. 


\section{GEOLOGY AND HYDROGEOLOGY}

Jibam village and environs is underlain by two major rock types, Basement Complex (Migmatites/Granites Gneiss) and Newer Basalt (Fig2). The stratigraphic succession within the study area is as summarized in Table 1.

Table 1: Geologic/Stratigraphic Succession around Jibam and Environs.

\begin{tabular}{|l|l|l|}
\hline & Rock Type/Formation & Age \\
\hline 3 & Newer Basalt & Quaternary \\
\hline 2 & Sub-Basalt alluvium & Paleogene-Neogene \\
\hline 1 & Migmatites/Granite-Gneiss & Pre-Cambrian (Archean-Proterozoic) \\
\hline
\end{tabular}

The Migmatites/Granite-Gneiss rocks in the study area comprises of schists, gneises, migmatites, marbles and quartzites.

The Newer basalt over lies the Basement Complex rocks. The basalt are formed from the lava which erupted from the vents of the volcanoes within the $\mathrm{Gu}$ line filling narrow and wide valleys flowing eastwards and southwards, coalescing to form an extensive sheet covering the Shemankar plains. Where there is accumulation of pre-volcanic sediments within the valleys, the laval flow buries the alluvium and form a subbasalt layer which is more of an "envelope" of sediments between the basalt and the basement1 (Plate 1). The alluvium, if consists essentially of gravels and sands, are very good aquifers (Offodile, 2003). The sub-basalt is usually traceable to ancient rivers or buried river/valley channels (Pre-volcanic).

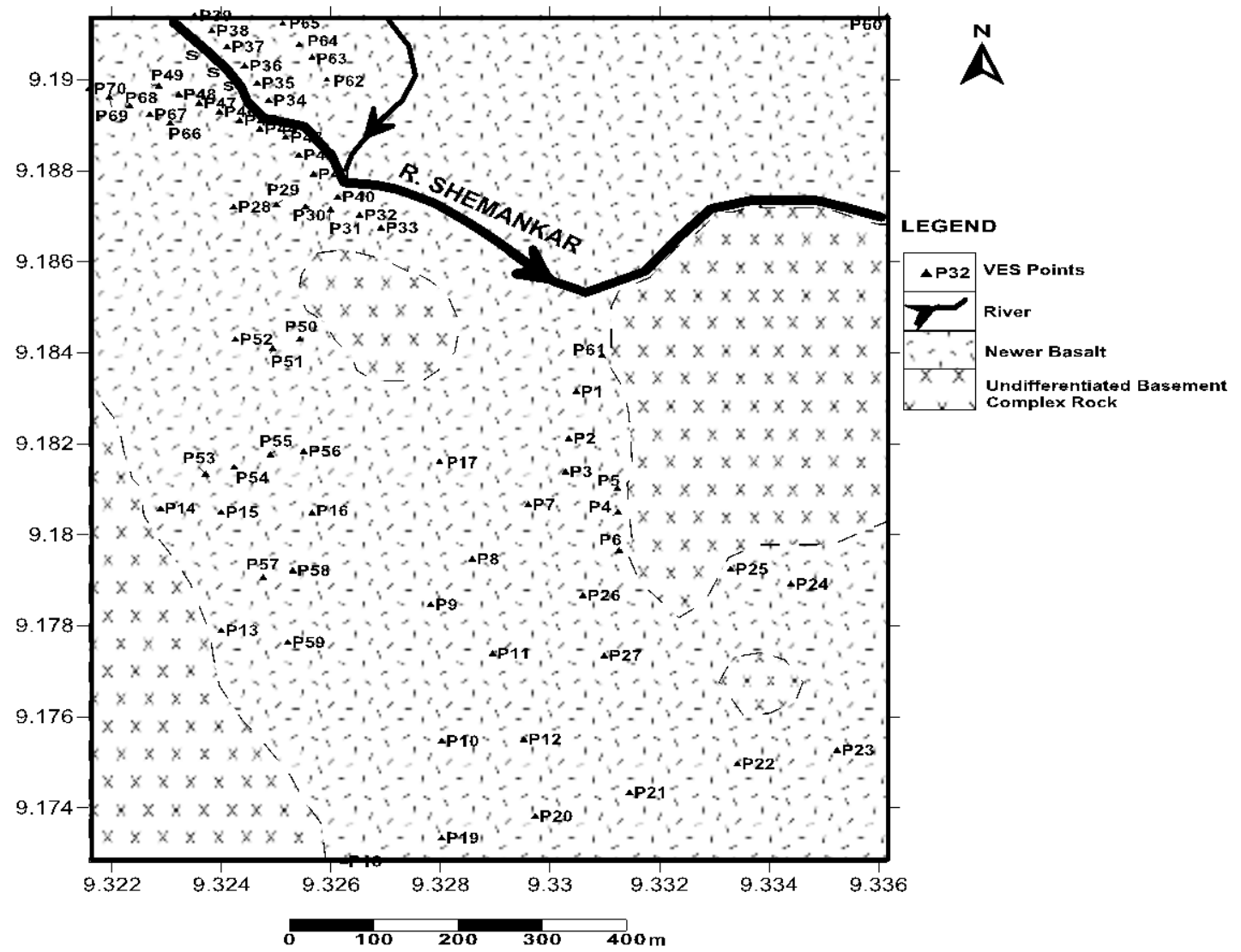

Fig. 2: Geological Map of the study area showing the Geoelectric

Sounding locations.

Three types of aquifers namely; fractured crystalline, soft or weathered and volcanic aquifers have been identified around Jibam and its environs. This is in good agreement with the three aquifer types reported by Ajaegbu et'al, 1992 on the Jos Plateau.

Around the study area, a successful borehole drilled encountered a sub-basalt alluvium and with a yield of $1.1 \mathrm{l} / \mathrm{s}$, (Fatigen Drilling, 2010). There are several spring that issues at near base of the River Shemankar, north of Jibam. The springs issues within the sub-basalt lithological section and are characteristically perennial (Plate 2). 


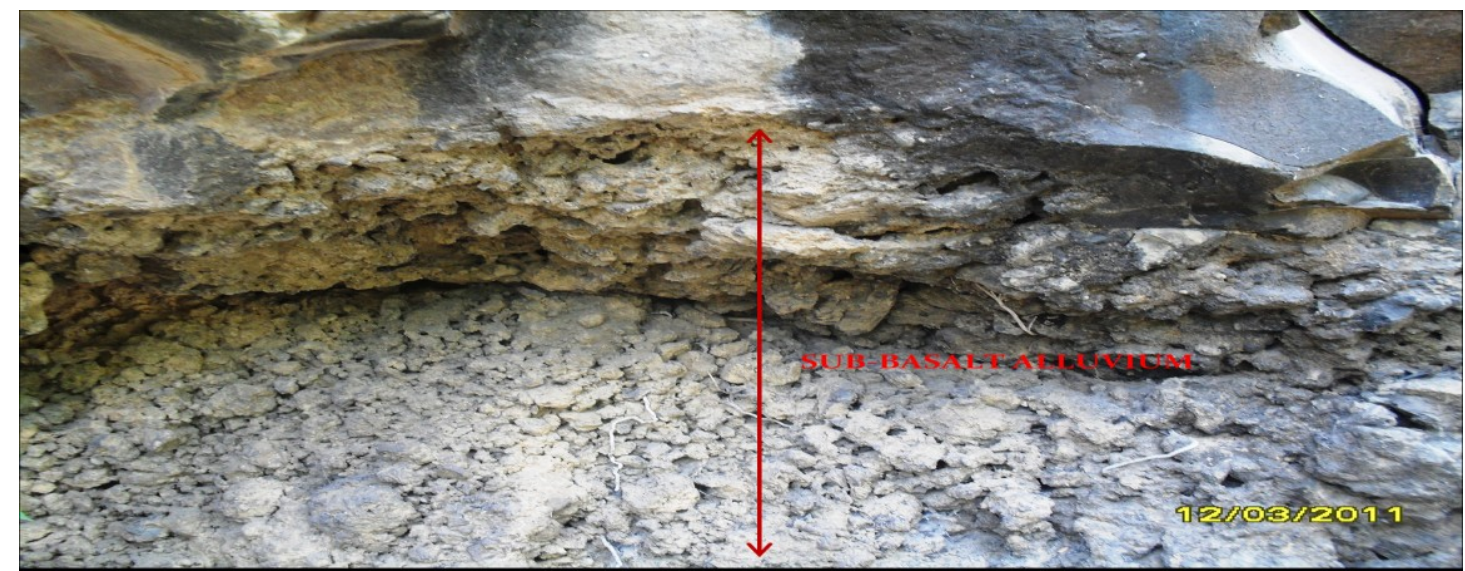

Plate 1: Sub-basalt Alluvium (Sands, Clays and Gravels intermix with lava) exposed within the River Shemankar.

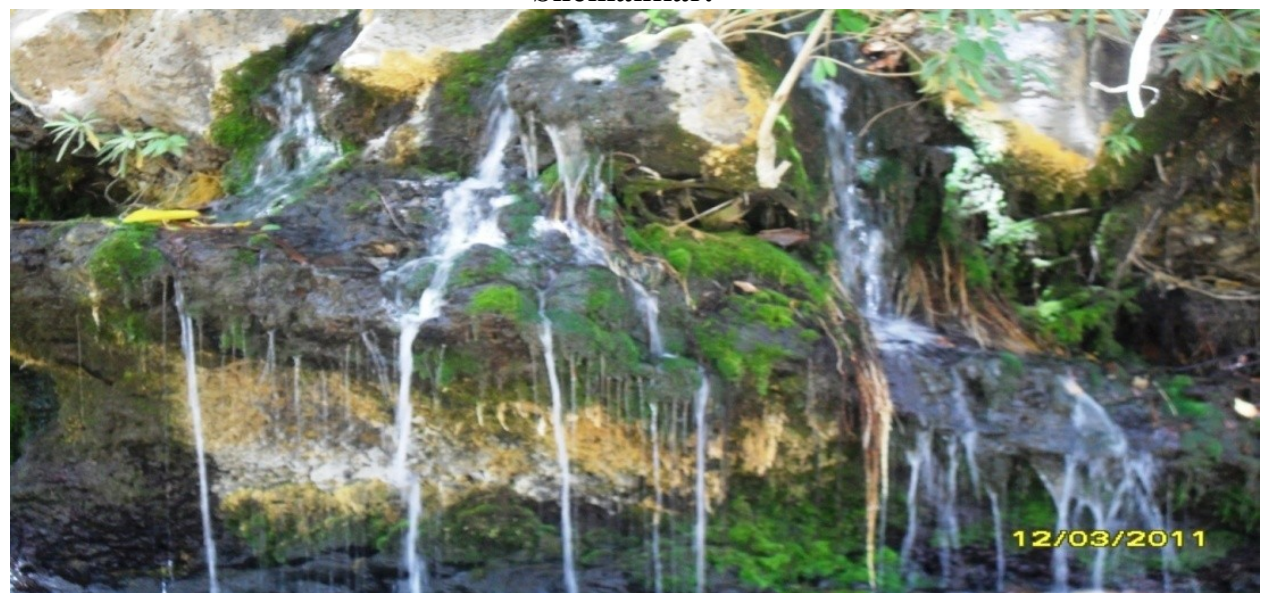

Plate 2: Volcanic Spring issuing out from sub-basalt/fractured basalt within the River Shemankar.

\section{Materials And Method.}

An integration of geological, hydrogeological and geophysical study was applied in this study.

The geological aspect involved surface mapping to determine the rock types and structural disposition especially geological structures relevant to groundwater occurrence (fractures in the form of faults, shear zones, etc.).

The hydrogeological investigations consists of generating data from existing hydraulic structures (wells and boreholes) to ascertain the static water level vis a vis the lithologic logs within the study area. The static water level were carried out using water level indicators (measuring tape) prior to abstraction through pumping in wells/boreholes. The measuring tape was lowered into the well until it reaches the water table; the static water level was then recorded from the measuring tape. Subsequently, the location coordinates and topographic elevations of the wells and boreholes within the study area were determined using GARMIN Etrex 12 channel portable Global Positioning System (GPS) unit.

Finally, electrical resistivity measurements employing the schlumberger array was carried out using ABEM Terrameter SAS 1000 series. A total of 70 geo-electric resistivity soundings (P1 to P70) were carried out in the study area. The current electrode spacing $(\mathrm{AB} / 2)$ was varied from 1.5 to $215 \mathrm{~m}$ and $500 \mathrm{~m}$.

The geophysical field data collected was interpreted using resistivity sounding interpretation software, Win Resist Version 1.0 (Vander Velpen, 1988, 2004). It is based on smoothness constrained optimization to define the geo-electric parameters as obtained from each geo-electric sounding data.

\section{Type Curves}

\section{Result And Discussion}

The interpretation of the VES data obtained for the research revealed searth models with geoelectric layers/lithologic units ranging from two (2) to six (6). The type curves representing geoelectric layers and their respective frequencies are shown in Table 2. 
Table 2: VES Type Curves and Frequency.

\begin{tabular}{|l|l|l|l|}
\hline $\begin{array}{c}\text { Type } \\
\text { curve }\end{array}$ & \multicolumn{1}{|c|}{ VES Points } & \multicolumn{1}{|c|}{$\begin{array}{c}\text { Frequency } \\
\text { Percentage } \\
\text { Frequency }\end{array}$} \\
\hline H & P44,P23,P15 & 3 & 4 \\
\hline A & P31,P60 & 2 & 3 \\
\hline HKA & P18,P36,P37,P48,P49,P63,P64,P67,P68 & 9 & 13 \\
\hline KH & P34 & 1 & 1 \\
\hline QH & P13,P24,P38,P39,P43 & 5 & 7 \\
\hline QKA & P4,P8,P26,P27,P35,P42,P46,P47 & 8 & 11 \\
\hline HA & P1,P2,P5,P6,P7,P9,P10,P11,P12,P14,P16,P19,P20,P21,P22,P25,P & 33 & 47 \\
& 28,P29,P30,P40,P45,P40,P45,P50,P51, & \\
\hline KA & P52,P56,P58,P59,P61,P62,P65,P66,P70 & & \\
\hline K & P3,P17,P32,P33,P53,P54,P55,P57 & 8 & 11 \\
\hline
\end{tabular}

The type curves were interpreted in terms of their hydrogeologic significance to serve as basis for the definition of aquifer architecture within the study area, since each of the type curves represents certain geometry of the geoelectric layers in the subsurface. Fig. 3 shows typical computer modeled VES curves in the study area.

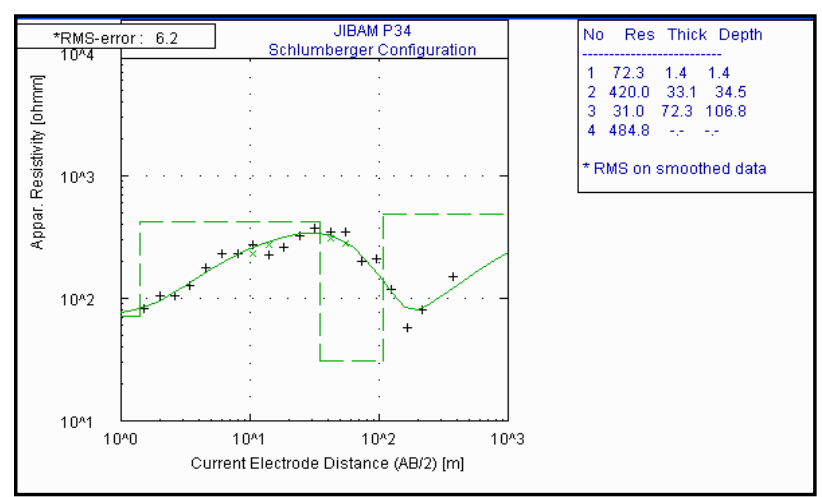

Fig. 3a: VES within the sub-basalt environs.
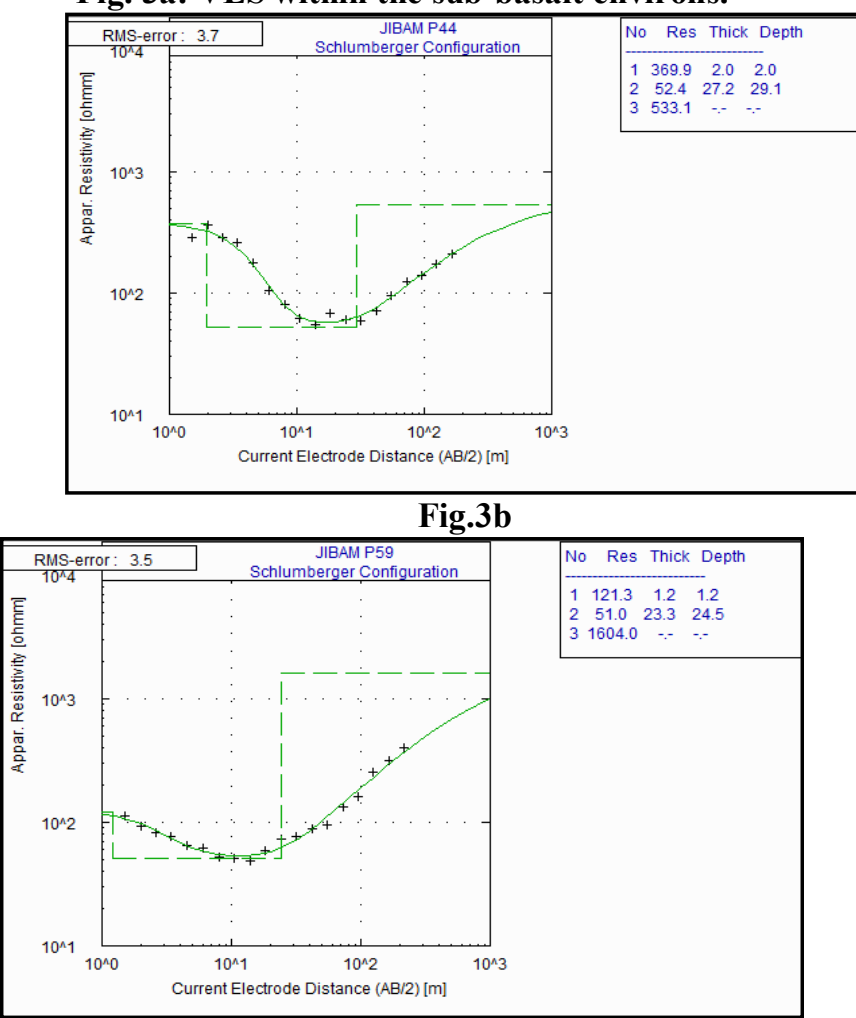

Fig. 3c

Fig. 3: Typical VES Curves from the Study Area. Geo-electrical parameters of the geo-electric sequence. 
From the geo-electric resistivity sounding data five (5) major lithologic units can be delineated in the study area - Topsoil, Weathered zone, Basalt/fractured basalt zone, Sub-basalt alluvium and the bedrock.

Correlative 2-D geo-electric sections (Figs. 4, 5, 6, 7 and 8) were taken in SE-NW, SW-NE and N-S across the study area with the aim of gaining an insight into the subsurface lithological disposition in the area.

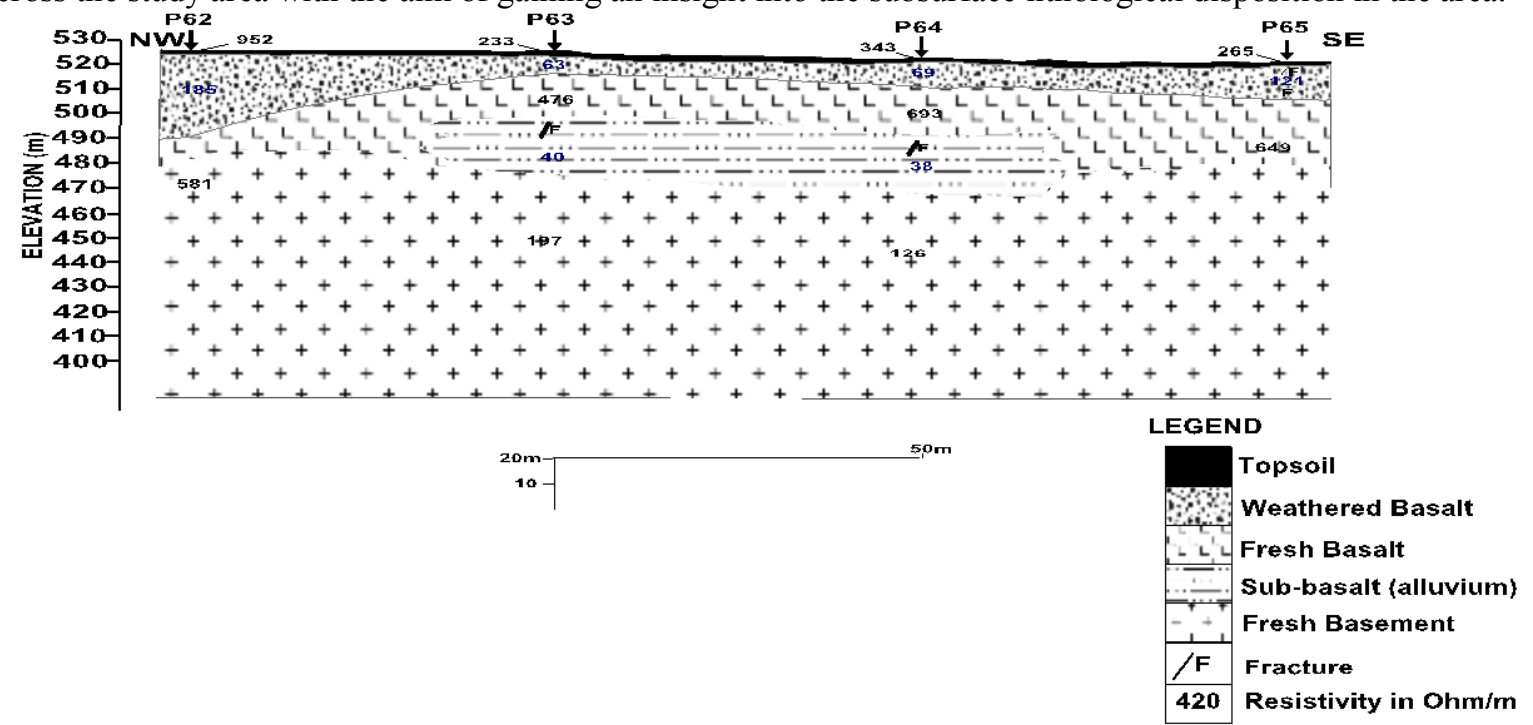

Fig. 4: Geo-electric Section along NW-SW Direction (P62-P65 axis).

The topsoil layer is from $0.9-3.8 \mathrm{~m}$ and characterized by resistivity value range from 93 to $634 \mathrm{ohm}-\mathrm{m}$. The low resistivity in the range of $\leq 100 \mathrm{ohm}-\mathrm{m}$ are characteristic of clay/clayey sands while those with resistivity $\geq 100 \mathrm{ohm}-\mathrm{m}$ are characteristic of lateritic clay/lateritic sandy clay/compact sand.

The thickness of the weathered layer varies from $0.1-21 \mathrm{~m}$ and characterized by low resistivity range of 23-152 ohm-m probably as a result of water saturation. This agrees with the assertion that significant saturation may be induced by reduction in resistivity (Omosuyi et'al, 2003).

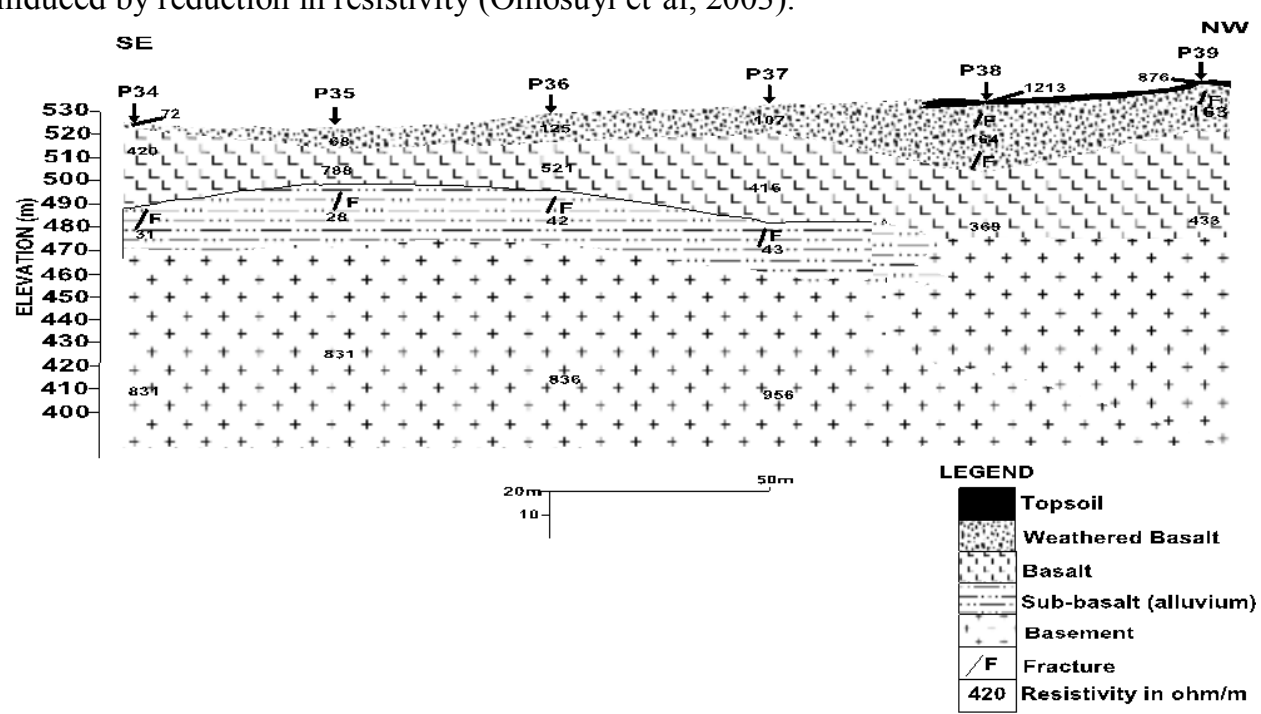

Fig. 5: Geo-electric Section along SE-NW Direction (P34-P39 axis).

The Basalt/fractured basalt thickness layer range from $0.1-20 \mathrm{~m}$ and it is characterized by high resistivity value range of 178-693 ohm-m indicating a fresh rock which is apparantly unweathered.

Geo-electric sections across P34-P39, P46-P35-P63, P53-P15-P57 and P62-P65 in SE-NW, SW-NE, NW-SE and NW-SW directions respectively (Fig. 4, 5, 6, and 7) correlates with borehole lithologic log (Fig. 9 and Fig 10) drilled on P15 and P37 respectively, revealed sub-basalt alluvium in the narrow and elongate stretched of the basalt filled valleys. The sub-basalt is characterized by resistivity values of 28 to $700 \mathrm{hm}-\mathrm{m}$, and with thickness of about $20-30 \mathrm{~m}$. This low resistivity can only be explained by the saturation of the aquifer. Perennial springs issues in the vicinity of P35 as a result of incision by present river course and exposes the subbasalt and /or fractures which the spring issues out from. 


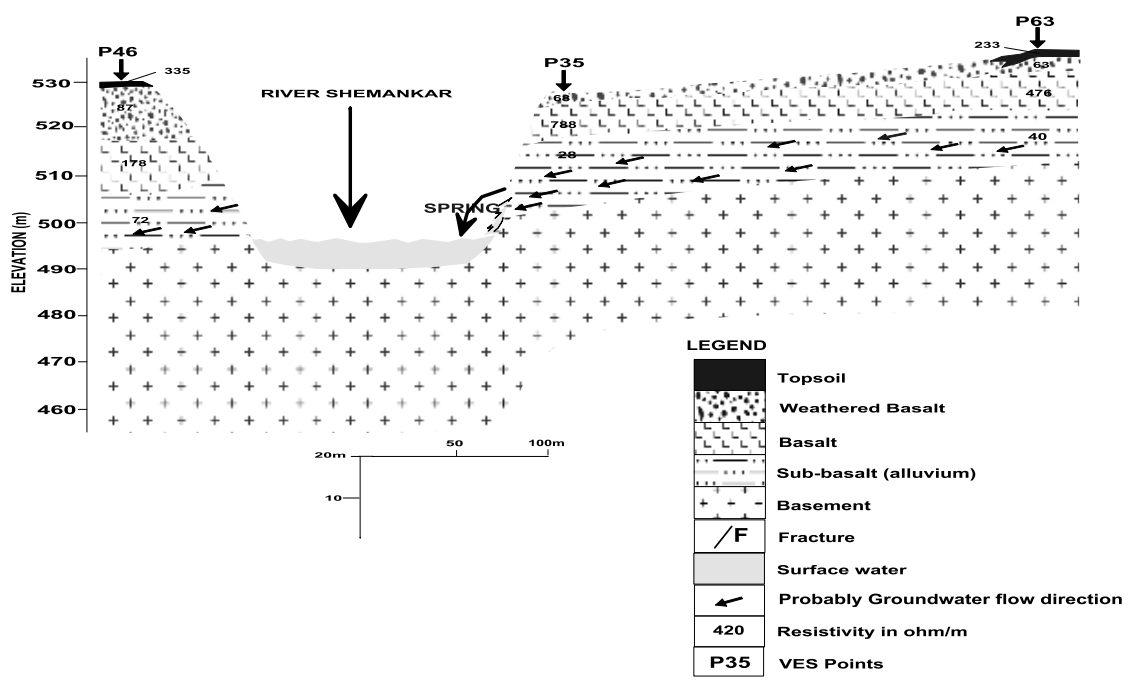

Fig. 6: Geo-electric Section along SW-NE Direction (P46-P63 axis).

The geo-electric section across P12-P4-P13 in N-S direction (Fig. 8) revealed fractures encountered at P4 with resistivity often $<200 \mathrm{ohm}-\mathrm{m}$ in the study area. Fractures when filled with water are aquiferous and these fractured aquifers can compliment weathered overburden aquifer overlying the bedrock.

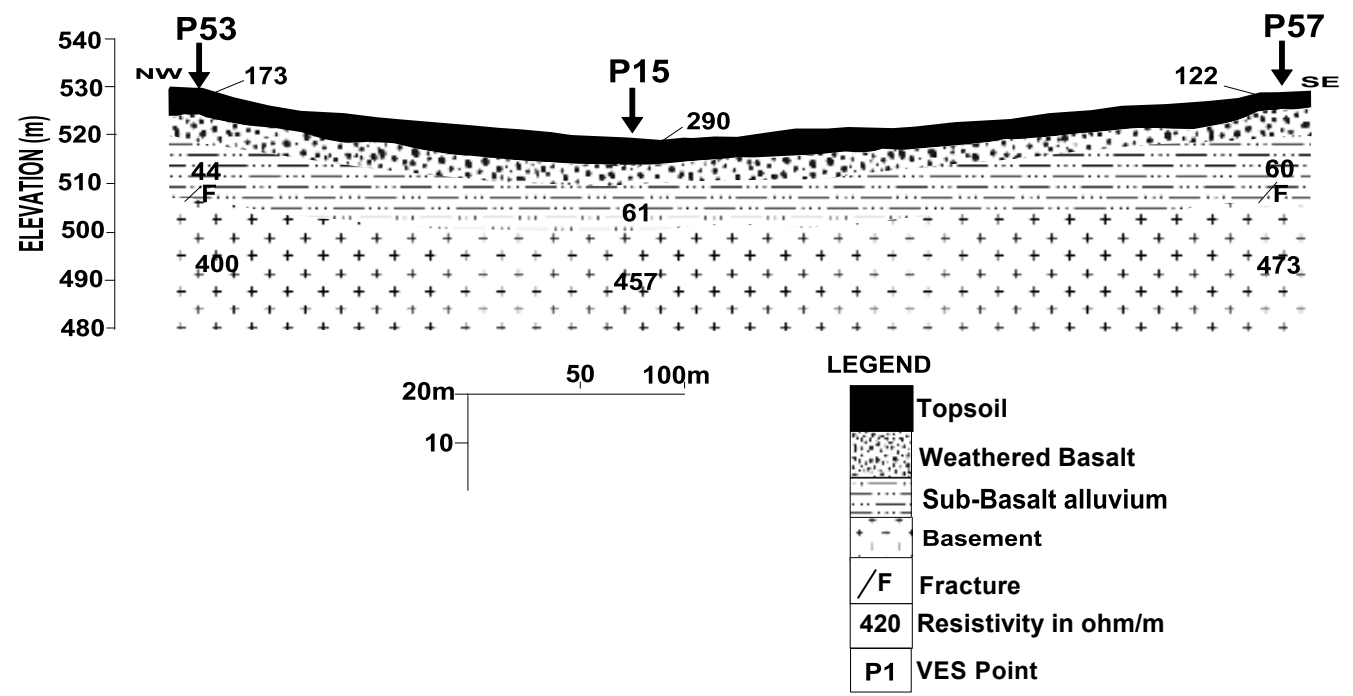

Fig. 7: Geo-electric Section along NW-SE Direction (P53-P15-P57 axis).

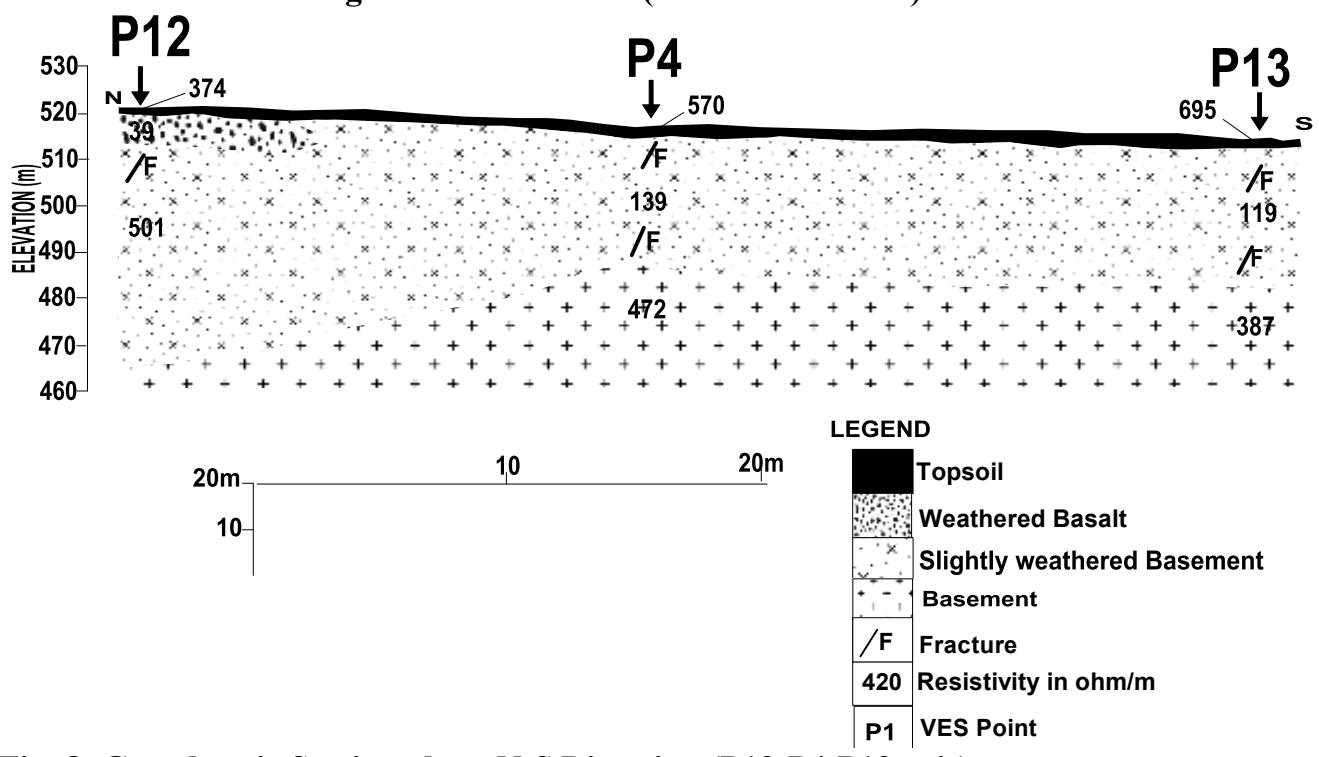

Fig. 8: Geo-electric Section along N-S Direction (P12-P4-P13 axis). 


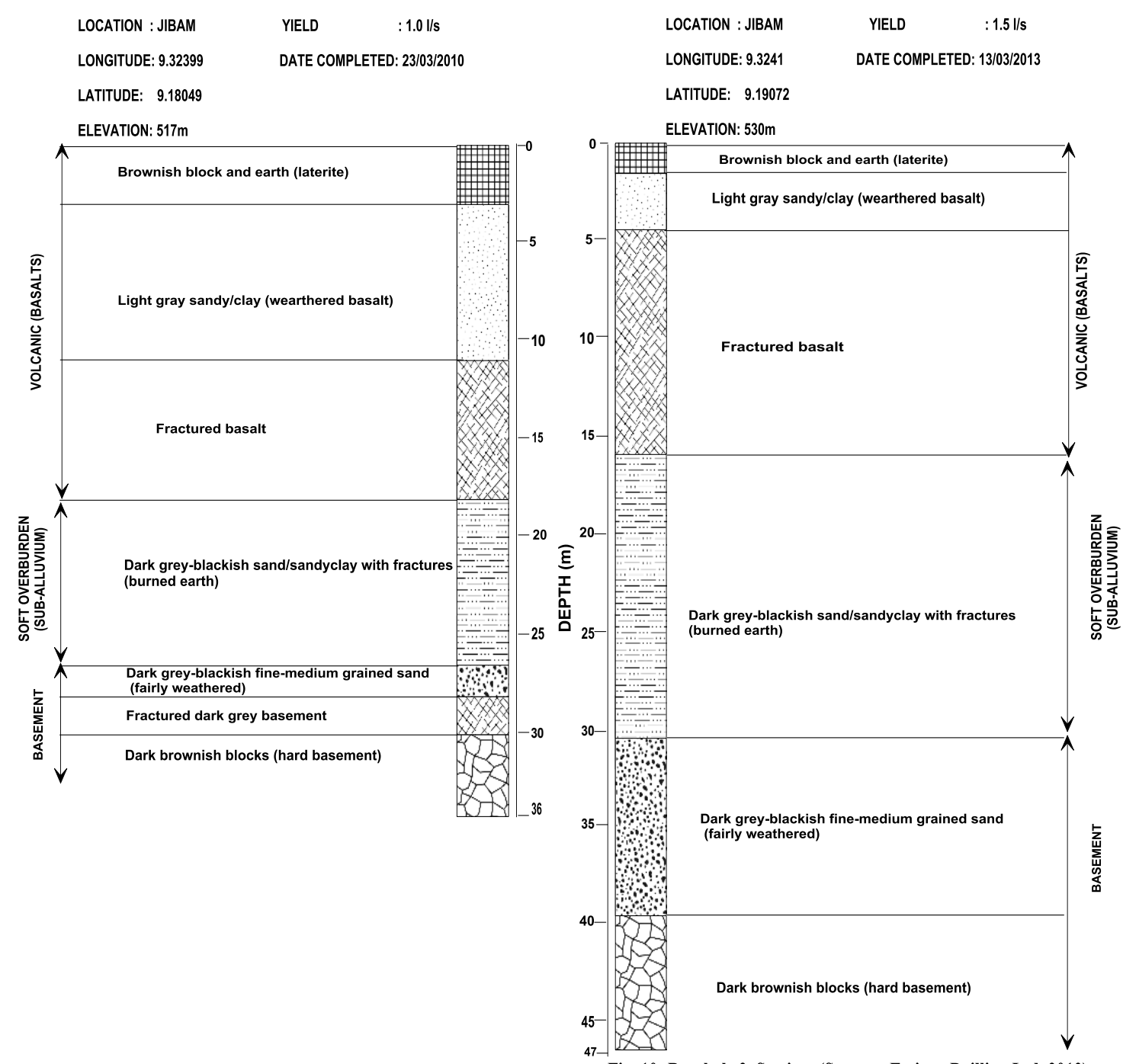

Fig. 9: Borehole 1 Section (Source: Fatigen Drilling Ltd, 2010)

Fig. 10: Borehole 2 Section (Source: Fatigen Drilling Ltd, 2013)

\section{Inferred Pre-volcanic River}

In figures 4, 5, 6 and 7 reveals variable thicknesses of inferred buried alluvial deposits where encountered between $9-35 \mathrm{~m}$ depth are presented. An extra-polation of these sections appears to reveal a prevolcanic river/valley which rises at the foot of a mountain north of the study area and flows for a short distance westwards, then southwards (Fig. 11). North of the study area, a post-volcanic gorge river hosting the upper reaches of Shemankar River exposed a section of the pre-volcanic river/valley alluvium (Fig. 6). The sub-basalt layer/fractured basement is characterized by perennial springs oozing from it as indicated along P34-P37 geoelectric section. The pre-volcanic river/valley alluvium is also exposed in the river section at P46 and appears to be a continuation of the river as inferred at P35 (Fig. 6).

Based on the geo-electric and river section lithology at P45-P49, the present river appears to have changed course over time which is different from the pre-volcanic period. 


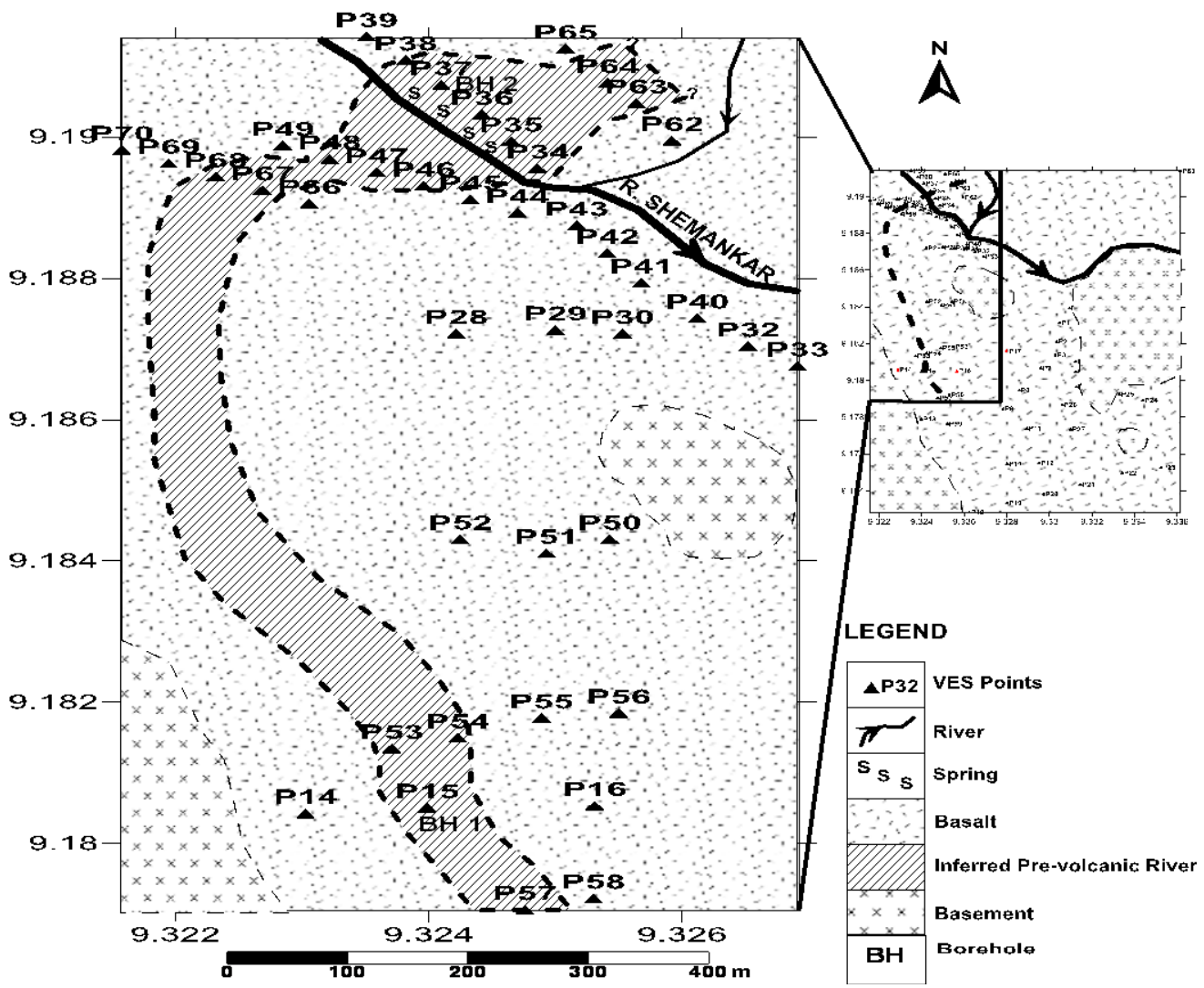

Fig. 11: Infered Pre-volcanic River.

\section{Isopach Map of Weathered Overburden}

The depth to basement established from the interpretation of VES sounding interpretation for each station occupied were plotted and contoured as isopach map (Fig. 11) using Surfer 9 GIS programme. The overburden thickness in the area varies from $<10$ to $25 \mathrm{~m}$

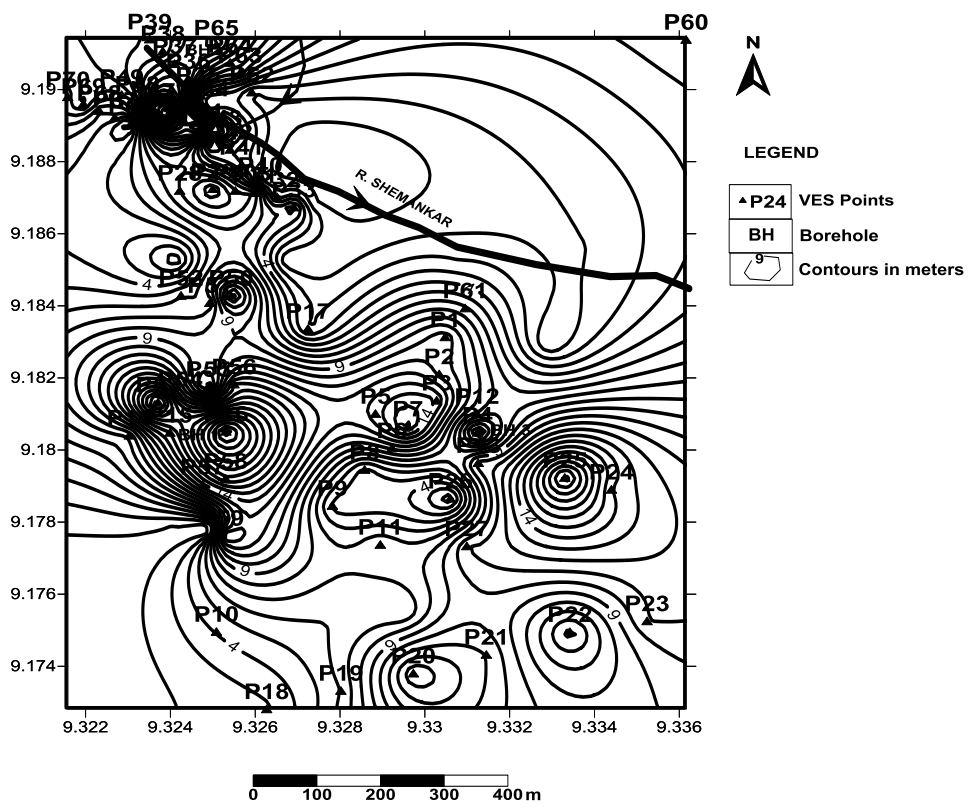

Fig. 12: Isopach Map of the Overburden.

The areas in the NE, SW, NW, SE and central parts of the study area has a relatively thin overburden $(<1$ to $10 \mathrm{~m})$, occupying approximately $85 \%$ of the study area. Areas with overburden thickness of $>10$ to $25 \mathrm{~m}$ occupies approximately $15 \%$ of the study area. 
Although zones of thick weathered overburden in basement terrain have been identified as areas of high groundwater potential (Okhue and Olorunfemi, 1991), the presumably thick overburden is not weathered material, but thick pegmatites rocks of the basement complex and is apparently dry.

\section{Basement Relief/Structural Map.}

A bedrock relief map is a reflection of the bedrock topography and its structural deposition is presented in Fig. 13. From this map, topographic ridges and depressions are identified. The ridges are marked by areas with thin overburden where as depression are marked by areas of thick overburden. The depressions are identified along the axis P36-P65, P50-P51-P52, P15-P16, P24-P25, and P6-P7 denoted by the symbols D1, D3, D5, D6 and D7 (Fig 13)

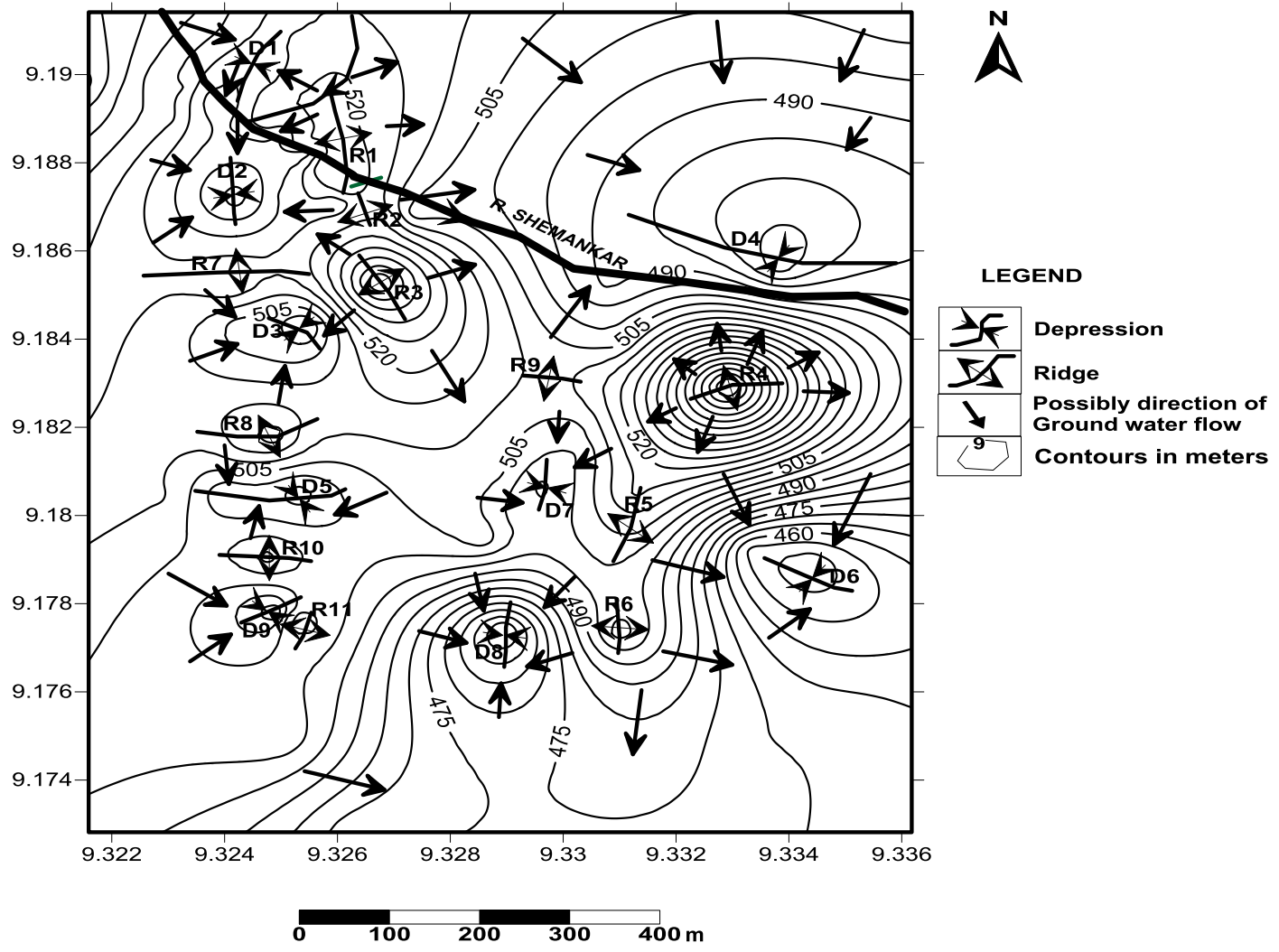

Fig. 13: Relief/Structural Map of the Bedrock.

The Inferred Pre-volcanic river/valley which rises from the basement hill north of the study area flows beneath depressions D1, D2 and D5. Along the river course, springs issues out at intersect of basement/alluvial contact and appears to be main contributor to the base flow of the River Shemankar.

\section{Groundwater Potential Evaluation}

From this study, the groundwater potential characterization is developed based on the geo-electric sections, isopach and basement relief maps prepared from geo-electric parameters as interpreted from the VES model curves (aided by borehole lithological information). According to this map (Fig. 14), there are basically two broad areas of groundwater yield, namely area of medium to high groundwater potential and areas of low groundwater potential. As fig. 14 illustrates, most of the VES locations estimated to have medium to high groundwater potential lie within the groundwater converging zone and the inferred pre-volcanic river stretching from the north-western to the central parts of the study area. In the groundwater radiating zone by contrast, there is equal possibilities of encountering low and medium groundwater yield locations. 


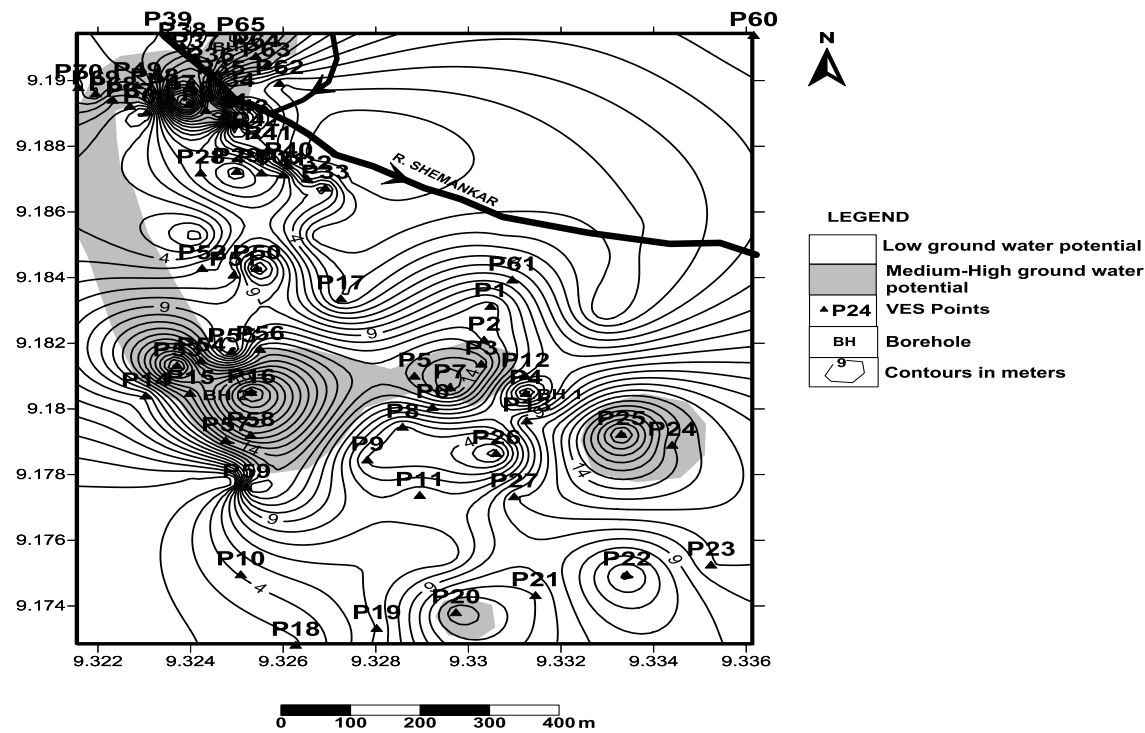

Fig. 14: Groundwater Potential Map.

\section{Conclusion}

The combined geological, hydrogeophysical and geophysical study have revealed the following:

I. The area is underlain by two major rock types, Migmatite/gneiss Complex (schists, gneisses, migmatites, marble and quartzites) and Newer Basalts.

II. Three major aquifer types have been identified which include, weathered overburden, fractured basement aquifer and sub-basalt alluvial aquifers.

III. The geo-electric sounding interpretation revealed 4-5 geoelectirc layers which include- Topsoil from 0$3.8 \mathrm{~m}$, Weathered basement/basalt from $0.1-21 \mathrm{~m}$, Basalt/fractured basalt from $0.1-20 \mathrm{~m}$, and Fresh basement from $10.1-\infty \mathrm{m}$, and characterized by variable resistivity value range from $93-634 \mathrm{ohm} / \mathrm{m}, 23-152 \mathrm{ohm} / \mathrm{m}$, $178-693 \mathrm{ohm} / \mathrm{m}$, and $100-1296 \mathrm{ohm} / \mathrm{m}$ respectively.

The finding of this study is expected to provide reliable baseline information for development of groundwater in the study area.

\section{Recommendation}

The volcanic springs found north of the study area can be utilized for small and medium scale water supply in the study area and adjoining villages.

\section{Acknowledgement}

The authors are grateful to Longpigrand Geotechnics Ltd for providing the ABEM Terrameter for the study for free. They wish to thank Joshua Mohoret Sati and Corslip Yahaya Africa who assisted in the field work.

\section{References}

[1]. Ajaegbu, H.I, Adepetu A.A, Ajakpo J, Ihemegbulem V.C, Jumbo S.E, Olaniyan J.A, Okechukwu G.C and Schoeneich K (1992): Jos Plateau Environmental Resources Development Programme: Jos Plateau Excursion Guide pp1.

[2]. Dakwo, P.D (2012): Hydrogeophysical Characteristics of Jibam and environs around Upper River Shemankar Basin, North Central Nigeria, Unpublished MSc Thesis, University of Jos

[3]. Longpia, C.B (2003): Hydrogeo-electric Characteristics of the Upper River Ndai Basin around the Kerang and Ampang Volcanoes, Jos-Plateau. Unpublished MSc Thesis, University of Jos.

[4]. Longpia, C.B (2010): Hydrogeo-electric Investigation of the Upper River Ndai Basin around the Ampang-Kerang volcanic line, JosPlateau. Journal of Engineering Science and Technology, Vol. 5 (3) PP 152-161.

[5]. Macleod WN, Turner DC, Wright EP (1971): Geology of the Jos Plateau. Vol.1 Bulletin 32, PP 1-118.

[6]. Omosuyi GO, Ojo JS, Erikanselu PA (2003): Geophysical Investigation for groundwater around Obanila-Obakekere in Akure Area within the basement complex of southwestern Nigeria. Journal of Mining and Geology Vol.39 (2) PP 109-116.

[7]. Offodile M.E. (2002): Groundwater Study and Development in Nigeria, $2^{\text {nd }}$ edition. Published by Mecon Geology and Engineering Services, Jos.

[8]. Okhue ET and Olorunfemi MO (1991): Electrical Resistivity Investigation of a Typical Basement Complex Area. The Obafemi Awolowo University, Campus Case Study. Journal of Mining and Geology Vol. 27(2), PP63-69.

[9]. Olorunfemi MO and Okhue ET (1992): Hydro geologic and Geologic Significance of a Geo -electric Survey at Ile-Ife. Journal of Mining and Geology (Vol. 28(2) PP 221-229.

[10]. Olorunfemi MO, Ojo JS and Akintunde OM (1999): Hydro geophysical Evaluation of the Groundwater Potentials of Akure Metropolis, SW Nigeria. Journal of Mining and Geology Vol. 35(2), PP 207-228. 